\title{
Effect of Different Levels of P Application and P Solubilizers on Growth Yield and Uptake Nutrient by Paddy
}

\author{
T. Shobha* and B. C. Dhananjaya \\ Department of Soil Science and Agricultural Chemistry, College of Agriculture, \\ Shivamogga, India \\ *Corresponding author
}

\begin{abstract}
A B S T R A C T
Keywords

Phosphorus,

Paddy,

available $P$,

PSF, PSB

Article Info

Accepted:

15 December 2019

Available Online:

20 January 2020

In order to know the effect of different levels of $\mathrm{P}$ application and $\mathrm{P}$ solubilizers on growth yield, and uptake nutrient by paddy a field experiment was conducted at Agricultural and Horticultural Research station Bavikere, during kharif seasion in 2017-18. The levels of phosphorus at $0,50,75$ and $100 \% \mathrm{P}_{2} \mathrm{O}_{5}$ as per ha ${ }^{-1}$ with and without $\mathrm{P}$ solubilizer seedling treatment were tried in a randomized complete block design (RCBD) with three replication and twelve treatments. Results of the field experiment indicated that treatment received recommended NPK with PSF seedling treatment significantly increased the growth and yield of paddy. Higher grain yield of paddy was noticed in treatment received recommended NPK with PSF seedling treatment. The higher nutrient content and uptake by paddy was noticed in treatment that received recommended NPK with PSF seedling treatment.
\end{abstract}

\section{Introduction}

Rice (Oryza sativa L.) is one of the important staple food crops for more than half of the world population, specially for south-eastern Asia, where 90 per cent of the world rice is grown and consumed. Globally, rice is cultivated in an area of 161.4 million hectares with the production of 506.3 million tonnes and productivity of 3.14 tonnes hectare ${ }^{-1}$. In India, the area under rice cultivation is 44.11 million hectare and production of 105.48 million tonnes with the productivity of 2391 $\mathrm{kg}$ hectare $^{-1}$ and Karnataka accounts for an area of 13.26 lakh hectare, production of 35.41 lakh tonnes and productivity of 2.67 tonnes hectare ${ }^{-1}$ (Anon., 2016). Phosphorus is one of the most important major nutrients required for the growth and development of 
crop plants. It plays a vital role in virtually every plant process like photosynthesis, energy storage and transfer, stimulating root development and growth, giving plant rapid and vigorous start leading to better tillering in wheat, and encouraging earlier maturity and seed formation. It also has a significant role in sustaining and building up of soil fertility, particularly under intensive system of agriculture. But, Phosphorus is one of the most immobile, inaccessible, and unavailable nutrient present in the soil.

Deficiency of soil phosphorus is one of the important chemical factors restricting plant growth in soils. Therefore, sufficient quantity of soluble form of phosphorus fertilizers is applied to achieve maximum plant productivity. However, the applied soluble forms of phosphatic fertilizers rapidly become unavailable to plants by conversion into inorganic $\mathrm{P}$ fractions that are fixed by chemical adsorption and precipitation. Similarly, organic P fractions are immobilized in soil organic matter. Phosphorus solubilizing microorganisms (bacteria and fungi) enable $\mathrm{P}$ to become available for plant uptake after solubilization. Several soil bacteria, particularly those belonging to the genera Bacillus and Pseudomonas, and fungi belonging to the genera Aspergillus and Penicillium possess the ability to bring insoluble phosphates in soil into soluble forms by secreting organic acids such as formic, acetic, propionic, lactic, glycolic, fumaric, and succinic acids. These acids lower the $\mathrm{pH}$ and bring about the dissolution of bound forms of phosphates. Venkateswarlu et al., have reported that during the solubilization of rock phosphate by fungi, the $\mathrm{pH}$ of the culture was lowered from 7 to 3 . Some of the hydroxy acids may chelate with calcium and iron resulting in effective solubilization and utilization of phosphates.

Several workers reported yield increasing on wheat, onion, alfalfa, and soybean through simple inoculation of P-solubilizing fungi (PSF). Kundu and Gaur reported that the grain and straw yields of rice increased significantly due to inoculations. They further reported that the phosphate solubilizing microorganisms improved phosphorus uptake over control with and without chemical fertilizers. There is lack of information on the use of PSM for paddy in under submerged condition. Therefore a field experiment was conducted to assess effect of different levels of $\mathrm{p}$ application and $\mathrm{p}$ solubilizers on growth yield, and uptake nutrient by paddy.

\section{Materials and Methods}

Field experiment was conducted at Agricultural and Horticultural Research station Bavikere, during the year 2017-18. The different levels of phosphorus at $0,50,75$ and $100 \% \mathrm{P}_{2} \mathrm{O}_{5}$ as DAP per ha ${ }^{-1}$ with and without $\mathrm{P}$ solubilizer seedling treatment were tried in a randomized complete block design (RCBD) with twelve treatments and three replication. The soil samples are air dried at room temperature. The initial soils have sandy clay loam in texture with $\mathrm{pH}$ of 5.98 with an organic carbon content $5.32 \mathrm{~g} \mathrm{~kg}^{-1}$. Further, the soil was low in nitrogen $\left(236.43 \mathrm{~kg} \mathrm{ha}^{-1}\right)$, high in phosphorus (89.51 kg ha-1) and medium in available potassium (193.32 $\left.\mathrm{kg} \mathrm{ha}^{-1}\right)$.

The experiment consists of twelve treatments with replicated three times and was laid out in a randomized complete block design with different levels of $\mathrm{P}$ solubilizers and P levels. The treatments include $\mathrm{T}_{1}$. RDF NK only $\mathrm{T}_{2}$. $\mathrm{RDF} \mathrm{NK}+\mathrm{PSB} \mathrm{T}_{3} . \mathrm{RDF} \mathrm{NK}+\mathrm{PSF}$ $\mathrm{T}_{4}$. $\mathrm{RDF} \mathrm{NK}+50 \% \mathrm{RDP} \mathrm{T}_{5}$. RDF NK + $50 \%$ of RDP + PSB $\mathrm{T}_{6}$. RDF NK $+50 \%$ of $\mathrm{RDP}+\mathrm{PSF} \mathrm{T}_{7} . \mathrm{RDF} \mathrm{NK}+75 \%$ of RDP $\mathrm{T}_{8}$. $\mathrm{RDF} \mathrm{NK}+75 \%$ of RDP $+\mathrm{PSB}_{9}$. RDF NK $+75 \%$ of RDP + PSF $\mathrm{T}_{10}$. RDF NPK $\mathrm{T}_{11}$. RDF NPK + PSB. $T_{12}$. RDF NPK + PSF and 10 tons FYM was common for all the treatments including control. Volume of the 
roots was measured by volume displacement method and expressed as cc plant ${ }^{-1}$. Five plants were uprooted at randomly from the adjacent to net plot area excluding two border rows each plot and were dried in hot air oven at $65^{\circ} \mathrm{C}$ for 72 hours until the constant weight. Then dry matter per plant was calculated at 30, 60, 90 DAP and at harvest of the crop The plant parts like, straw, root and grain samples were collected plot-wise at the time of harvest and were dried at $60^{\circ} \mathrm{C}$ in hot air oven after a thorough cleaning with water, then powdered using a grinder. Then analysis of N P K done using standard procedure. The crop was harvested, threshed and dried in the sun. The grains were cleaned and weight was recorded and straw after threshing was dried in the sun, weighed and expressed in $\mathrm{kg}$ per hectare.

\section{Results and Discussion}

Higher total dry weight was recorded in treatment received recommended NPK with PSF seedling treatment (22.71 $\mathrm{mg} \mathrm{kg}^{-1}$ ) followed by treatment received recommended NPK with PSB seedling treatment compared to other treatments. Higher values of root volume recorded in treatment received recommended NPK with PSF seedling treatment followed by treatment received recommended NPK with PSB seedling treatment compared to other treatments The similar trend was also noticed in accumulation.

This might be due to $\mathrm{P}$ application and its continuous availability as it plays an important role in growth, development and photosynthesis which might have reflected in higher values for total dry matter as also reported Phosphorus fertilization increased the total plant dry matter mass as reported by Bukvic et al., (2003). These results are in agreement with the findings of Asuming et al., (2014) and Krishnababu et al., (2006).
Higher test weight recorded in treatment received recommended NPK with PSF seedling treatment $(23.24 \mathrm{~g})$ followed by treatment received recommended NPK with PSB seedling treatment. Higher number of panicles per plant recorded in treatment received recommended NPK with PSF seedling treatment $((19.67)$ followed by treatment received recommended NPK with PSB seedling treatment.

Highertotal grains panicle $^{-1}$ recorded in treatment received recommended NPK with PSF seedling treatment (155.67) followed by treatment received recommended NPK with PSB seedling treatment. Number of panicles, grains per panicles and test weight was higher due to high $\mathrm{P}$ availability in soil, which in turn influenced the physiological processes that are directly related to photosynthesis and carbohydrate translocation to panicle growth and it was observed by Abbas Akbari et al., (2010). Higher grain and straw yield were recorded in the treatment received $\mathrm{RDF}+$ PSF was applied $\left(\mathrm{T}_{12}\right)$ followed by $\mathrm{T}_{11}$ (RDF $+\mathrm{PSB}), \mathrm{T}_{10}(\mathrm{RDF})$ and $\mathrm{T}_{9}(\mathrm{RD}-\mathrm{N} \& \mathrm{~K}+75 \%$ RD-P + PSF). Among these four treatments, application of RDF with PSF found to be better compared to rest of the treatments as it has recorded higher $\mathrm{B}: \mathrm{C}$ ratio (2.7).

The increase in grain and straw yield in $T_{12}$ followed by $T_{11}$ and $T_{10}$ treatments might be attributed to the higher growth and yield parameters due to graded levels of $\mathrm{P}$ and $\mathrm{P}$ solubilizers treatment. Tariq Masood et al., (2011) also reported that the growth and yield of paddy increased significantly with increased level of $\mathrm{P}$ applied Singh and Ahlawat (2007) also reported a similar increase in yield by phosphorus application.

The significant increase in straw yield of rice is in agreement with the findings of Pandey et al.,

(2007). 
The content of $\mathrm{N}, \mathrm{P}$ and $\mathrm{K}$ by grain, straw Highest by paddy significantly varied among treatments involving only $\mathrm{P}$ levels and $\mathrm{P}$ levels with $\mathrm{P}$ solubilizers seedling treatment. Higher nitrogen, phosphorus and potassium content in grain $(1.46 \%, 0.34 \%$ and $1.43 \%$ respectively ) and straw (1.52, 0.36, and $1.51 \%$ respectively ) was recorded in treatment received recommended NPK with PSF seedling treatment $\left(\mathrm{T}_{12}\right)$ and followed treatment received recommended NPK with PSB seedling treatment compare to other treatment. Significantly lowercontent of N, P and $\mathrm{K}$ by grain and straw recorded in treatment received recommended NK only. The uptake of N, P and K by grain, straw and total uptake by paddy significantly varied among treatments received only $\mathrm{P}$ levels and
$\mathrm{P}$ levels with $\mathrm{P}$ solubilizers seedling treatment.

Higher nitrogen, phosphorus and potassium content in grain (83.36 18.67 and $81.36 \mathrm{~kg}$ ha ${ }^{1}$ respectively ), straw $(103.38,24.17$, and $101.97 \mathrm{~kg} \mathrm{ha}^{-1}$ respectively ) and total uptake of paddy (186.74, 43.27 and $183.33 \mathrm{~kg} \mathrm{ha}^{-1}$ respectively) was recorded in treatment received recommended NPK with PSF seedling treatment $\left(\mathrm{T}_{12}\right)$ and followed treatment received recommended NPK with PSB seedling treatment compare to other treatment. Significantly lower uptake of N, P and $\mathrm{K}$ by grain, straw and total uptake by paddy recorded treatment received recommended NK only.

Table.1 Effect of $\mathrm{P}$ levels and $\mathrm{P}$ solubilizers seedling treatment on total dry matter accumulation and root volume at different growth stages of paddy

\begin{tabular}{|c|c|c|c|c|c|}
\hline \multirow[t]{2}{*}{ Treatments } & \multicolumn{4}{|c|}{ Total dry matter accumulation (g hill ${ }^{-1}$ ) } & \multirow{2}{*}{$\begin{array}{l}\text { Root } \\
\text { volume } \\
\left(\text { cc plant }{ }^{-1}\right)\end{array}$} \\
\hline & 30 DAP & 60 DAP & 90DAP & Harvest & \\
\hline$T_{1}:$ Recommended NK only & 3.15 & 12.80 & 25.68 & 39.39 & 4.67 \\
\hline $\mathrm{T}_{2}$ : Recommended NK + PSB & 3.25 & 13.78 & 26.27 & 40.16 & 5.00 \\
\hline $\mathrm{T}_{3}:$ Recommended NK + PSF & 3.37 & 14.93 & 27.37 & 44.58 & 5.00 \\
\hline $\mathrm{T}_{4}$ : Recommended NK + $50 \%$ Recommended P & 4.25 & 16.00 & 29.71 & 46.00 & 5.33 \\
\hline $\mathrm{T}_{5}:$ Recommended NK + $50 \%$ Recommended P + PSB & 4.93 & 20.38 & 36.57 & 51.46 & 5.67 \\
\hline $\mathrm{T}_{6}:$ Recommended NK + $50 \%$ Recommended P + PSF & 5.24 & 22.11 & 39.67 & 53.40 & 6.67 \\
\hline$T_{7}:$ Recommended NK + $75 \%$ Recommended P & 5.42 & 23.74 & 41.45 & 58.08 & 6.67 \\
\hline $\mathrm{T}_{8}$ : Recommended NK + $75 \%$ Recommended P +PSB & 6.24 & 26.78 & 48.72 & 63.22 & 7.0 \\
\hline $\mathrm{T}_{9}$ : Recommended NK + $75 \%$ Recommended P +PSF & 7.01 & 28.55 & 51.48 & 66.12 & 7.37 \\
\hline$T_{10}:$ Recommended NPK & 7.98 & 30.30 & 52.33 & 68.52 & 8.04 \\
\hline$T_{11}:$ Recommended NPK + PSB & 8.96 & 34.97 & 56.67 & 72.24 & 8.14 \\
\hline$T_{12}:$ Recommended NPK + PSF & 9.42 & 36.49 & 58.00 & 74.12 & 8.33 \\
\hline S. Em. \pm & 0.26 & 1.01 & 1.56 & 1.46 & 0.42 \\
\hline C.D. $(p=0.05)$ & 0.76 & 2.96 & 4.56 & 4.29 & 1.23 \\
\hline
\end{tabular}


Table.2 Effect of P levels and P solubilizers seedling treatment on test weight, number of panicles, total grains per panicle, grain and straw yield of paddy

\begin{tabular}{|c|c|c|c|c|c|}
\hline \multirow[t]{2}{*}{ Treatments } & \multirow{2}{*}{$\begin{array}{l}\text { Test } \\
\text { weight } \\
(\mathrm{g})\end{array}$} & \multirow{2}{*}{$\begin{array}{l}\text { Number } \\
\text { of } \\
\text { panicles } \\
\text { plant }^{-1}\end{array}$} & \multirow{2}{*}{$\begin{array}{l}\text { Total } \\
\text { grains } \\
\text { panicle }^{-1}\end{array}$} & $\begin{array}{l}\text { Grain } \\
\text { yield }\end{array}$ & $\begin{array}{l}\text { Straw } \\
\text { yield }\end{array}$ \\
\hline & & & & \multicolumn{2}{|c|}{$\left(\mathbf{q} \mathbf{h a}^{-1}\right)$} \\
\hline$T_{1}$ : Recommended NK only & 18.36 & 12.67 & 119.00 & 35.08 & 45.41 \\
\hline $\mathrm{T}_{2}:$ Recommended NK + PSB & 19.38 & 14.33 & 128.33 & 40.07 & 49.77 \\
\hline $\mathrm{T}_{3}:$ Recommended NK + PSF & 19.92 & 15.00 & 129.00 & 40.33 & 50.38 \\
\hline $\begin{array}{l}\mathrm{T}_{4}: \text { Recommended } \mathrm{NK}+50 \% \\
\text { Recommended P }\end{array}$ & 19.93 & 15.33 & 128.33 & 41.15 & 50.66 \\
\hline $\begin{array}{c}\mathrm{T}_{5}: \text { Recommended NK }+50 \% \\
\text { Recommended P + PSB }\end{array}$ & 20.76 & 17.00 & 137.67 & 46.57 & 54.82 \\
\hline $\begin{array}{c}\mathrm{T}_{6}: \text { Recommended NK + } 50 \% \\
\text { Recommended P + PSF }\end{array}$ & 20.88 & 17.33 & 140.00 & 47.15 & 55.02 \\
\hline $\begin{array}{l}\mathrm{T}_{7}: \text { Recommended NK + } 75 \% \\
\text { Recommended P }\end{array}$ & 21.02 & 17.00 & 139.71 & 47.29 & 58.32 \\
\hline $\begin{array}{c}\mathrm{T}_{8}: \\
\text { Recommended NK }+75 \% \\
\text { Recommended P +PSB }\end{array}$ & 22.63 & 18.50 & 149.33 & 52.56 & 64.26 \\
\hline $\begin{array}{c}\text { T }_{9}: \text { Recommended NK + } 75 \% \\
\text { Recommended P +PSF }\end{array}$ & 22.63 & 18.67 & 150.67 & 53.98 & 64.57 \\
\hline$T_{10}:$ Recommended NPK & 22.06 & 18.33 & 149.33 & 52.68 & 63.99 \\
\hline$T_{11}:$ Recommended NPK + PSB & 23.24 & 19.33 & 153.85 & 55.92 & 67.38 \\
\hline$T_{12}:$ Recommended NPK + PSF & 23.78 & 19.67 & 155.67 & 56.90 & 67.78 \\
\hline S. Em. \pm & 0.23 & 0.44 & 2.86 & 1.78 & 1.33 \\
\hline C.D. $(p=0.05)$ & 0.68 & 1.28 & 8.40 & 5.23 & 3.91 \\
\hline
\end{tabular}

Note: FYM is common to all the treatments PSB: Phosphorus Solubilizing Bacteria PSF: Phosphorus Solubilizing Fungi DAP

Days after planting 
Table.3 Effect of P levels and P solubilizers seedling treatment on nitrogen and phosphorus content of grain and straw of paddy

\begin{tabular}{|c|c|c|c|c|c|c|}
\hline \multirow[t]{2}{*}{ Treatments } & \multicolumn{2}{|c|}{ Nitrogen content (\%) } & \multicolumn{2}{|c|}{$\begin{array}{l}\text { Phosphorus } \\
\text { content (\%) }\end{array}$} & \multicolumn{2}{|c|}{$\begin{array}{l}\text { Potassium content } \\
(\%)\end{array}$} \\
\hline & Grain & Grain & Grain & Straw & Grain & Straw \\
\hline$T_{1}:$ Recommended NK only & 1.03 & 0.21 & 0.21 & 0.22 & 1.28 & 1.35 \\
\hline $\mathrm{T}_{2}:$ Recommended NK + PSB & 1.09 & 0.22 & 0.22 & 0.22 & 1.29 & 1.37 \\
\hline$T_{3}:$ Recommended NK + PSF & 1.10 & 0.23 & 0.23 & 0.23 & 1.30 & 1.37 \\
\hline $\begin{array}{l}\mathrm{T}_{4}: \text { Recommended NK }+50 \% \\
\text { Recommended P }\end{array}$ & 1.15 & 0.24 & 0.24 & 0.24 & 1.31 & 1.39 \\
\hline $\begin{array}{c}\mathrm{T}_{5}: \text { Recommended NK + } 50 \% \\
\text { Recommended P + PSB }\end{array}$ & 1.22 & 0.26 & 0.26 & 0.26 & 1.34 & 1.42 \\
\hline $\begin{array}{c}\mathrm{T}_{6}: \text { Recommended NK + } 50 \% \\
\text { Recommended P + PSF }\end{array}$ & 1.21 & 0.26 & 0.26 & 0.27 & 1.31 & 1.39 \\
\hline $\begin{array}{l}\mathrm{T}_{7}: \text { Recommended NK }+75 \% \\
\text { Recommended P }\end{array}$ & 1.23 & 0.29 & 0.29 & 0.30 & 1.33 & 1.41 \\
\hline $\begin{array}{c}\mathrm{T}_{8}: \text { Recommended NK + } 75 \% \\
\text { Recommended P +PSB }\end{array}$ & 1.29 & 0.28 & 0.28 & 0.30 & 1.36 & 1.44 \\
\hline $\begin{array}{c}\mathrm{T}_{9}: \text { Recommended NK + } 75 \% \\
\text { Recommended P +PSF }\end{array}$ & 1.30 & 0.30 & 0.30 & 0.34 & 1.39 & 1.47 \\
\hline$T_{10}:$ Recommended NPK & 1.43 & 0.33 & 0.33 & 0.33 & 1.41 & 1.49 \\
\hline$T_{11}:$ Recommended NPK + PSB & 1.46 & 0.33 & 0.33 & 0.34 & 1.42 & 1.50 \\
\hline$T_{12}:$ Recommended NPK + PSF & 1.46 & 0.34 & 0.34 & 0.36 & 1.43 & 1.51 \\
\hline S. Em. \pm & 0.07 & 0.03 & 0.03 & 0.03 & 0.03 & 0.03 \\
\hline C.D. $(p=0.05)$ & 0.20 & 0.09 & 0.09 & 0.08 & 0.08 & 0.08 \\
\hline
\end{tabular}

Note: FYM is common to all the treatments PSB: Phosphorus Solubilizing Bacteria PSF: Phosphorus Solubilizing Fungi DAP - Days after planting 
Table.4 Effect of P levels and P solubilizers seedling treatment on nitrogen and phosphorus uptake by paddy

\begin{tabular}{|c|c|c|c|c|c|c|c|c|c|}
\hline \multirow[t]{3}{*}{ Treatments } & \multicolumn{3}{|c|}{ Nitrogen uptake } & \multicolumn{3}{|c|}{ Phosphorus uptake } & \multicolumn{3}{|c|}{ Potassium uptake } \\
\hline & \multicolumn{9}{|c|}{$\left(\mathrm{kg} \mathrm{ha}^{-1}\right)$} \\
\hline & Grain & Straw & Total & Grain & $\begin{array}{l}\text { Stra } \\
\text { w }\end{array}$ & Total & Grain & Straw & Total \\
\hline$T_{1}$ : Recommended NK only & 36.00 & 54.34 & 90.34 & 7.48 & 10.01 & 17.50 & 44.81 & 61.43 & 106.25 \\
\hline $\mathrm{T}_{2}:$ Recommended NK + PSB & 43.55 & 64.21 & 107.75 & 8.90 & 11.12 & 20.01 & 51.69 & 68.02 & 119.72 \\
\hline$T_{3}:$ Recommended NK + PSF & 44.82 & 65.24 & 110.06 & 9.36 & 11.75 & 21.11 & 52.28 & 69.25 & 121.53 \\
\hline $\begin{array}{l}\mathrm{T}_{4}: \text { Recommended NK + } 50 \% \\
\text { Recommended P }\end{array}$ & 47.36 & 67.20 & 114.56 & 9.88 & 12.16 & 22.03 & 54.02 & 70.41 & 124.43 \\
\hline $\begin{aligned} T_{5}: & \text { Recommended NK + } 50 \% \\
& \text { Recommended P + PSB }\end{aligned}$ & 56.76 & 72.35 & 129.11 & 11.95 & 14.25 & 26.21 & 62.38 & 77.79 & 140.17 \\
\hline $\begin{array}{c}\text { T }_{6}: \text { Recommended NK + 50 \% } \\
\text { Recommended P + PSF }\end{array}$ & 57.25 & 75.94 & 133.19 & 12.26 & 14.87 & 27.13 & 61.81 & 76.48 & 138.29 \\
\hline $\begin{array}{l}\mathrm{T}_{7}: \text { Recommended NK + } 75 \% \\
\text { Recommended P }\end{array}$ & 57.94 & 82.22 & 140.15 & 13.80 & 17.28 & 31.08 & 62.88 & 82.04 & 144.92 \\
\hline $\begin{aligned} T_{8}: & \text { Recommended NK + } 75 \% \\
& \text { Recommended P+PSB }\end{aligned}$ & 67.63 & 88.34 & 155.97 & 14.89 & 19.29 & 34.18 & 71.69 & 92.57 & 164.26 \\
\hline $\begin{aligned} T_{9}: & \text { Recommended NK + } 75 \% \\
& \text { Recommended P+PSF }\end{aligned}$ & 70.14 & 88.77 & 158.91 & 16.20 & 22.06 & 38.25 & 75.22 & 94.99 & 170.21 \\
\hline$T_{10}:$ Recommended NPK & 75.20 & 92.44 & 167.64 & 17.36 & 21.19 & 38.55 & 74.46 & 95.39 & 169.85 \\
\hline $\begin{array}{l}T_{11}: \text { Recommended NPK }+ \\
\text { PSB }\end{array}$ & 81.37 & 99.63 & 181.00 & 18.67 & 23.17 & 41.84 & 79.43 & 100.87 & 180.30 \\
\hline $\begin{array}{l}T_{12}: \text { Recommended NPK + } \\
\text { PSF }\end{array}$ & 83.36 & 103.38 & 186.74 & 19.10 & 24.17 & 43.27 & 81.36 & 101.97 & 183.33 \\
\hline S. Em. \pm & 4.47 & 3.70 & 7.10 & 1.09 & 1.62 & 2.50 & 3.03 & 2.27 & 4.59 \\
\hline C.D. $(p=0.05)$ & 13.11 & 10.84 & 20.82 & 3.19 & 4.76 & 7.33 & 8.87 & 6.65 & 13.46 \\
\hline
\end{tabular}

Note: FYM is common to all the treatments PSB: Phosphorus Solubilizing Bacteria PSF: Phosphorus Solubilizing Fungi, DAP - Days after planting

Content and uptake varied significantly both in straw and grain due to the application of graded levels of $\mathrm{P}$ and $\mathrm{P}$ solubilizers. This might be due to the quantity of dry biomass production and increase in $\mathrm{P}$ availability at higher $\mathrm{P}$ levels. Phosphorus content in with $\mathrm{P}$ fertilizer recorded higher $\mathrm{P}$ content due to high soluble $\mathrm{P}$ which enables higher uptake. Kishore Babu and Seshaiah (2006) observed that concentration and uptake of nutrients in grain and straw increased linearly with an increase in $\mathrm{P}$ levels in combinations with organic manures and PSF. The results are in agreement with the findings of Laxminarayana (2005) and Desai et al., (2009).

In the study, $\mathrm{P}$ levels with $\mathrm{P}$ solubilizers seedling treatment perform better than without seedling treatment with respect to grain yield, $\mathrm{P}$ levels with $\mathrm{P}$ solubilizers seedling treatment can be recommended in 
the study area. Phosphorus is a growth limiting nutrient in the acid soil. So, the application of phosphorus @ 100\% RDP with $\mathrm{P}$ solubilizers is beneficial and found on par with $75 \%$ RDP with P solubilizers

\section{References}

Abbas Akbari, G. H., Eftekhari, G. H. and Allahdadi, I., 2010, Evaluation of rock super phosphates effects on yield and yield components of Rice (Oryza sativa L.) with and without phosphate solubilizing bacteria. Am. J. Agron., 3(3):51-58

Anonymous, 2016, Bureau of Economics and Statistics. Govt of India.

Asuming, B. M., Rempong, S. and Anipa, B., 2014, The use of rock phosphate and phosphate solubilizing fungi (Aspergillus niger) to improve the growth and the yield of upland rice on typickandiudal. West African J. Applied Ecol., 22(1):27-39.

Bukvic, G., Antunovic, M., Popovic, S. and Rastija, M., 2003, Effect of $\mathrm{P}$ and $\mathrm{Zn}$ fertilization on biomass yield and its uptake by maize lines (Zea mays L.). $P l$. Soil Environ., 49(11):505-510.

Desai, R. M., Patel, G. G., Patel, T. D. and Das, A., 2009, Effect of integrated nutrient supply on yield, nutrient uptake and soil properties in rice-rice crop sequence. J. Indian Soc. Soil Sci.,
57(2):172- 17

Kishore Babu, G and Seshaiah, B. V., 2006, Effect of phosphates on yield and nutrient uptake in paddy Department of Soil Science and Agricultural Chemistry, Agricultural College, Bapatla-522 101, India. Agropedology, 16(1):50-53.

Kundu, B. S. and Gaur, A. C., 1983, Rice response to inoculation with $\mathrm{N} 2$-fixing and $\mathrm{P}$ solubilizing micro-organism. $\mathrm{Pl}$. Soil, 79:227-234.

Laxminarayana, K., 2005, Effect of integrated use of inorganic and organic manures on soil properties, yield and nutrient uptake of rice in ultisols of Mizoram. $J$. Indian Soc. Soil Sci., 54(1):120-123.

Pandey, N., Verma, A. K., Anurag and Tripathi, R. S., 2007, Integrated nutrient management in transplanted hybrid rice (Oryza sativa). India J. Agron., 52:4042.

Singh, U. and Ahlawat, I.P.S., 2007, Phosphorus management in pigeon peawheat cropping system. Indian $J$. Agron., 52(1):21-26.

Tariq Masood, Rozina Gul, Fazal Munsif, Fazal Jalal, Zahid Hussain, Nadia Noreen, Hamayoon Khan, Nasiruddin And Hayatullah Khan, 2011, Effect of different phosphorus levels on the yield and yield components of maize. Sarhad J. Agric. 27(2):167.

\section{How to cite this article:}

Shobha. T. and Dhananjaya. B. C. 2020. Effect of Different Levels of P Application And P Solubilizers on Growth Yield and Uptake Nutrient by Paddy. Int.J.Curr.Microbiol.App.Sci. 9(01): 1660-1667. doi: https://doi.org/10.20546/ijcmas.2020.901.183 